\title{
Okul Öncesi Öğretmenlerinin Sanat ve Yaratıcılık Kavramlarına İlişkin Algıları
}

\section{Pre-School Teachers' Perceptions of Art and Creativity Concepts}

Ayhan Bulut ${ }^{\mathrm{a}, *}$

${ }^{a}$ Dr. Öğr. Üyesi, Bayburt Üniversitesi, Bayburt Eğitim Fakültesi, Temel Eğitim Bölümü, 69000, Bayburt/Türkiye. ORCID: 0000-0001-6482-8032

\section{MAKALE BİLGİSI \\ Makale Geçmişi: \\ Başvuru tarihi: 20 Eylül 2019 \\ Düzeltme tarihi: 26 Şubat 2020 \\ Kabul tarihi: 12 Mart 2020}

\section{Anahtar Kelimeler:}

Okul öncesi

Sanat

Yaratıcilık
ÖZ

$\mathrm{Bu}$ araştırmanın amacı okul öncesi öğretmenlerinin sanat ve yaratıcılık kavramlarına ilişkin görüşlerini belirlenmektir. Araştırma nitel araştırmaya dayalı tipik durum deseninde gerçekleştirilmiştir. Araştırmanın çalışma grubunu çalışmaya gönüllü olarak destek veren 40 okul öncesi öğretmeni oluşturmaktadır. Araştırmada veri toplama aracı olarak, okul öncesi öğretmenlerin sanat ve yaratıcılık kavramlarına ilişkin görüşlerinin incelenmesi için geliştirilen görüşme formu kullanılmıştır. Elde edilen verilerin çözümlenmesinde içerik analizi ve betimsel analiz yaklaşımı bir arada kullanılmıştır. Araştırma bulgularından elde edilen verilere göre okul öncesi öğretmenlerinin öğrenme ortamında sanat ve yaratıcılıkla ilgili faaliyetler olarak, öğrencilerine en çok resim çizme ve boyama etkinlikleri yaptırdıkları belirlenmiştir. Okul öncesi öğretmenleri, öğrenme ortamında uyguladıkları sanatsal faaliyetlerin çocukların yaratıcılıkları üzerinde çoğunlukla, kendi bireysel yeteneklerinin farkına varmalarını sağladığını ifade etmişlerdir.

\section{A B S T R A C T}

The research aims to determine the views of preschool teachers on the concepts of art and creativity. The research was conducted in a standard case pattern grounded on qualitative research. The study group of the research consists of 40 preschool teachers who voluntarily support the study. In the research, the interview form created to analyze the opinions of preschool teachers about the concepts of art and creativity was employed as the data collection tool. Content analysis and descriptive analysis approaches were employed together in examining the obtained data. According to the data collected from the research findings, it was concluded that preschool teachers mostly preferred the drawing and painting activities for their students, associated with art and creativity in the learning environment. Preschool teachers said that the artistic activities they present in the learning environment chiefly assist children in achieving their abilities in their creativity.

\section{Giriş}

Erken çocukluk dönemindeki eğitim süreci, bireyin tüm yönleriyle gelişim sürecinde kritik ve hassas bir döneme denk gelmektedir ve oldukça önemli bir yere sahiptir. Bireyin şahsiyeti ve mizacı, genel olarak çocukluk çağında gelişir (Senemoğlu, 2004). Bireyin önemli gelişim evrelerinde yer alan bu dönemde, çocukların içinden geçecekleri eğitimin niteliği ve çevresindeki uyarıcıların sağlıklı bir şekilde dizaynı, öğrenme süreçleri üzerinde etkilidir. Çocukların gelişimsel süreçleriyle birlikte, ahlaki gelişimlerinin yanı sıra, entelektüel ve estetik gelişimlerinin de desteklenmesi gerekmektedir (Aykanat, 2018). Çocuğun kişiliğinin dişa yansıması olan sanat hareketleri ilk olarak bu yıllarda başlamaktadır (Artut, 2004). Okul öncesi eğitim dönemi yapılan sanatsal etkinliklerin, çocukların kendinde var olan beceri ve yeteneklerinin farkına varmasını sağlayarak onların, yaratıcı yönlerini şekillendirdiği görülmektedir (Yazıcı, Baydar ve Pinarcik, 2016).

\footnotetext{
* Sorumlu yazar/Corresponding author.

e-posta: ayhanbulut@bayburt.edu.tr
} 
Sanat, kelimelerin dilini, renklere, çizgilere, șekillere ve çeşitli dokunuşlara bıraktığı bir iletişim ve etkileşim dilidir (Hardy, 2011). Sanat, insanın yaşama gözlerini açtığı günden başlayarak erken eğitim döneminde kendini hissettirdiği, hayata bakış açılarıyla ve hayalleri ile büyüttüğü tecrübelerinin harmanlanmasıdır (Jackman, 2012). Sanat, çocukların gelişimlerini desteklemek ve yaratıcılıklarını ön plana çıkarmak için onlara sonsuz sayıda firsatlar veren bilginin kritik ve önemli şekilleridir (Hardy, 2011; Lucas, 2014). İçinde yaşadığımız modern çağ sürekli değişimin yaşandı̆̆ı, bilginin hızlı tüketildiği, yenilenmenin kaçılmaz olduğu bir dönem olarak kabul edilmektedir. Bu dönemde çağdaş dünyanın bir parçası olmak isteyen toplumlar, erken yaşlarda çocuklara yapıcı ve yaratıcı bir bakış açısı kazandırmalıdır. Eğitimin önemli bir parçası olan yaratıcılık, bir sorunun çözümüne özgün ve farklı bir bakış açısı kazandırmaya dayalı bilişsel bir etkinlik olarak açıklanabilir (Solso, Maclin, \& Maclin, 2011). "Barker (2002: 23) yaratıcılığı yenilikler ortaya koyan zihinsel bir faaliyettir olarak tanımlamaktadır." Sawyer'a (2011:36) göre yaratıcılık "bilimsel bir kavram değildir, mekâna ve zamana göre değişen kültürel ve tarihsel olarak spesifik bir fikirdir". Okul öncesi dönemde sanat eğitimi uygun şekilde hazırlandığında çocukların yaratıcılıklarını geliştiren büyük bir potansiyel olmaktadır. Duygularını dille, müzikle ve programdaki diğer etkinliklerle ifade edemeyen çocuklar, sanat etkinlikleri ile kendilerini ifade etme imkânı bulmakta ve rahatlamakta, kendilerine özgü yeni ürünler oluşturarak doyuma ulaşmaktadırlar (Ulutaş ve Ersoy, 2004). Uysal'a (2005) göre, çocuk eğitim aracılığıyla yaratıcılığa teşvik edilmelidir.

Okul öncesi dönemde sanat eğitimi; çocuklar için estetik bakış açısının gelişimi ile tutum ve becerileri edinmeleri açısından önemli bir etkiye sahiptir. Okul öncesi öğretmenleri ve öğretmen adayları da sanat etkinliklerini planlama ve uygulama sürecinde yeterli bilgi ve beceriye sahip olarak çocuklar için bu süreci eğlenceli ve öğretici bir hale getirmelidir (Gönen, Aydos ve Erdem, 2016). Yaratıc1, kendine güvenen, üretken ve estetik duygulara sahip bireylerin yetiştirilmesi sanat eğitimi ile mümkündür. Sanat eğitimi, bireye sahip olduğu zihinsel birikimi ve deneyimlerini açıklama ve yorumlama firsatı verir. Bireyler, bir şeyler yapmanın ve yaratmanın sonucunda daha mutlu ve üretken kişiler haline gelirler (Yavuzer, 2005). Kırışoğlu (2002) sanatsal yaratıcılığın ancak planlı ve programlı bir eğitimle gelişeceğini belirtmiştir. Okul öncesi eğitim dönemi de bu çocukların örgün eğitimle ilk tanıştığı planlı ve programlı bir eğitimle karşılaştıkları ilk eğitim sürecidir.

Çocukların sanatla ilgili temel kavramları öğrenerek, sanatsal ve estetik bir bakış açısı kazanarak yaratıcı ve özgün eserler ortaya çıkarmasında öğretmenlerin konuyla ilgili yaklaşım ve davranışları çok önemlidir (Cevher ve Kalburan, 2012). Öğretmenler bu süreçte çocukların sanatla ilgili içsel bir farkındalık geliştirmesine olanak sağlayarak, onların içinde yaşadıkları toplumun kültürünü, tarihini ve sosyal yapısını kendi bakış açılarıyla yansıtabilecekleri yaratıcı eserler üretmesine imkânlar hazırlamalıdır (Garvis, 2012).

Okul öncesi eğitim tüm dünyada örgün eğitimin başlangıcı ve çocukların eğitim sürecinde kritik öneme sahip hassas bir dönem olarak görülmektedir. $\mathrm{Bu}$ dönemin niteliği ve zenginliği, okul öncesi öğretmenlerinin sanat ve yaratıcılık kavramlarına yönelik bakış açılarının belirlenmesi bu araştırmanın problem konusunu oluşturmaktadır.
$\mathrm{Bu}$ araştırma okul öncesi öğretmenlerinin sanat ve yaratıcılığa verdiği değeri ortaya çıkarması, sanat ve yaratıcılık açısından zengin öğrenme yaşantılarına rehberlik edeceği düşüncesiyle oldukça önemli görülmektedir. Ayrıca, öğretmen adaylarına sanat ve yaratıcılık açısından izleyecekleri yol ve ulaşabilecekleri hedefleri belirlemeleri noktasında kaynak oluşturacaktır.

$\mathrm{Bu}$ çalışmanın amacı, okul öncesi öğretmenlerinin sanat ve yaratıcılık kavramlarına ilişkin algılarını tespit etmektir. Bu amaç altında şu sorulara cevap aranmıştır.

1. Öğretmenlerinin sanat ve yaratıcılık kavramlarıyla ilgili görüşleri nelerdir?

2. Öğrenme ortamında uyguladıkları sanat ve yaratıcılıkla ilgili faaliyetler nelerdir?

3. Uyguladıkları sanat faaliyetlerin çocukların yaratıcılıkları üzerindeki etkisine yönelik görüşleri nelerdir?

4. Uyguladıkları sanat ve yaratıcılıkla ilgili faaliyetlerin, çocukların gelişim süreçleri üzerindeki etkisine yönelik görüşleri nelerdir?

5. Sanat ve yaratıcılık açısından kendilerini nasıl tanımladıklarına ilişkin görüşleri nelerdir?

\section{Yöntem}

Bu bölümde araştırmanın deseni, çalışma grubu, veri toplama araçları, verilerin toplanması ve analizi hakkında bilgi verilmektedir.

\subsection{Araştırma Deseni}

Okul öncesi öğretmenlerinin sanat ve yaratıcılık kavramlarına ilişkin görüşlerinin incelendiği bu çalışmada nitel yaklaşımlarından biri olan tipik durum deseni (case study) kullanılmıştır. Nitel araştırmada genel olarak takip edilen araştırma süreci parçadan bütüne yani tüme varmayı amaçlar. $\mathrm{Bu}$ yüzden de nitel araştırmalar teorinin olmadığı ya da var olan teorinin sosyal olayları açıklamada yetersiz kaldığı durumlarda tercih sebebidir (Merriam, 1998). Durum desenleri nitel araştırmalarda ve sosyal bilimlerde sıklıkla kullanılan desenlerden biri olarak bilimsel araştırmalara ve sorulara cevap arayan ayırt edici bir yaklaşım olarak da tanımlanmaktadır (Yin, 2018). Ayrica nitel durum çalışmalarının en belirgin özelliklerinden biri de bir veya birden fazla durumun derinlemesine incelenmesine olanak sağlamasıdır (Yıldırım ve Şimşek, 2011).

\section{2. Çalışma Grubu}

Okul öncesi öğretmenlerinin sanat ve yaratıcılık kavramlarına ilişkin görüşlerinin belirlendiği araştırmada amaçlı örnekleme yöntemlerinden ölçüt örneklem kullanılmıştır. Amaçlı örnekleme, zengin bilgiye sahip olduğu düşünülen durumların derinlemesine çalıșılmasına olanak vermektedir (Patton, 1987). Ölçüt örnekleme yönteminin en belirgin özelliği önceden belirlenmiş bir dizi ölçütü karşılayan bütün durumların çalışılmasına olanak sağlamasıdır. Burada sözü edilen ölçüt veya ölçütler araştırmacı tarafından oluşturulabilir ya da daha önceden hazırlanmış bir ölçüt listesi kullanılabilir (Yıldırım ve Şimşek, 2011). Buna bağlı olarak, bu araştırmada kullanılan ölçütler, araştırma konusunun taşıdığı özeliklerden hareketle araştırmacı tarafından oluşturulmuştur. Bu çalışma grubunda ölçüt olarak, çalışmaya katılan öğretmenlerin anaokulları bünyesinde yer alan 60-66 aylık gruplarda görev yapıyor olmalarına ve öğretmenlerin mesleki kıdemlerinin 
çalışmayı etkileyeceği düşüncesiyle, öğretmenlerin en az mesleklerinde 4 yıl ve üstü kıdeme sahip olmalarına dikkat edilmiştir. Araştırmanın çalışma grubuna giren öğretmenlerin 10'unun Erzurum ili Yakutiye ilçesinde, 22'sinin Palandöken ilçesinde ve 8'inin Aziziye ilçesinde görev yaptığı tespit edilmiştir. Araştırmanın çalışma grubunda yer alan öğretmenlerin (\%95- f:38) bayan; (\%5- f:2) erkek öğretmenlerden oluşturmaktadır. Ayrıca çalışma grubuna giren öğretmenlerin (\%55- f:22); 35-40 yaş aralığında; (\%20 f:8); 40-45 yaş aralığında; (\%15- f:6) 45 yaş ve üstü yaş aralığında; ( (\%10- f:4), 30-35 yaş aralığında olduğu tespit edilmiştir. Öte yandan araştırmanın çalışma grubuna giren öğretmenlerin (\%42,5- f: 17), 10-15 y1l arası mesleki kıdeme sahip olduklar1; (\% 27,5- f:11), 15-20 yıl arası kıdeme sahip oldukları, (\%17,5- f:7), 20-25 yıl arası kıdeme sahip oldukları, (\%7,5- f:3), 25 yıl ve üstü kıdeme sahip oldukları, (\%5- f:2) 05 yıl arası kıdeme sahip oldukları belirlenmiştir.

\subsection{Veri Toplama Araci}

Araştırmada veri toplama aracı olarak, okul öncesi öğretmenlerin sanat ve yaratıcılık kavramlarına ilişkin görüşlerini incelemek için araştırmacı tarafından geliştirilen yarı yapılandırılmış görüşme formu kullanılmıştır. Görüşme süreci araştırmacılara görüşme yaptığı kişinin verdiği cevaplar doğrultusunda konu hakkında derinlemesine bilgi edinme imkânı sağlar (Güler, Halıcıoğlu ve Taşğın, 2013). Nitel araştırmalarda genellikle kullanılan yarı-yapılandırılmış görüşmeler, araştırmacılara konunun ana çerçevesini belirleyip kendi konuları kapsamında soru sorma firsatı verirken, aynı zamanda görüşme esnasında ortaya çıkabilecek yeni koşullara göre sorular eklemeye olanak tanıyan esnek bir yap1 sunar (Dinç, 2015). Yapılması planlanan görüşmeler için literatür taranmış, elde edilen bu literatür taraması sonucunda sorular oluşturularak yarı yapılandırılmış görüşme formu hazırlanmıştır. Görüşme formu ilk etapta tüm araştırma problemlerini kapsayacak nitelikte altı sorudan oluşturulmuştur. Daha sonra görüşme formunun geçerliğini arttırmak için Eğitim Programları ve Öğretim ana bilim dalından iki Dr. Öğr. Üyesi ile Okul Öncesi Öğretmenliği ana bilim dalında Dr. Öğr. Üyesi olarak görev yapan bir uzmanın görüşüne başvurulmuştur. Uzmanların konuyla ilgili görüşleri doğrultusunda görüşme formunda yer alan sorular tekrar gözden geçirilmiş, eksik görülen yerler tamamlanmış ve bu aşamada yer alan bir soru uzman görüşleri doğrultusunda amaca uygun olmadığı gerekçesiyle formdan çıkarılmış ve başlangıç aşamasında altı olan soru sayısı beşe düşürülerek forma son şekli verilmiştir. Araştırma örneklemine girmeyen dört okul öncesi öğretmeniyle ön pilot uygulama olarak görüşmeler yapılmış ve görüşme formunun geçerliliği ve kullanışlılığ görüşme sorularının yeterli düzeyde açık ve anlaşılır olduğu sonucuna ulaşılmıştır.

\subsection{Verilerin Toplanmas1}

Araştırma verileri, çalışma gurubuna giren okul öncesi öğretmenleriyle yarı yapılandırılmış görüşme formu kullanılarak gerçekleştirilen yüz yüze görüşmeler yoluyla toplanmıştır. Çalışma grubuna giren öğretmenlerden randevu alınarak ve görev yaptıkları okullara gidilerek yaklaşık 15- 20 dakikalık görüşmeler gerçekleştirilmiştir. Görüşme esnasında araştırmaya katılan öğretmenlere araştırma sürecine ilişkin ön bilgilendirmeler yapılmıştır. Görüşme esnasında veri kaybını önlemek için kayıt cihazı kullanılmıştır. Katılımcılardan bu konuda gerekli izinler alınmış, görüşmenin sonunda tutulan kayıtların kendileri tarafından tümden dinlenebileceği ve gerektiği durumlarda kayıtlardaki görüşlerin kısmen veya tamamen kendi isteklerine bağlı olarak çıkarılabileceği belirtilmiştir.

\subsection{Verilerin Analizi}

Araştırma sürecinden elde edilen verilerin çözümlenmesinde içerik analizi ve betimsel analiz yaklaşımı birlikte kullanılmış ve veriler özetlenerek yorumlanmıştır. Araştırma sürecinden elde edilen verilerin analizi herhangi bir program kullanılmadan gerçekleştirilmiştir. İçerik analizinde hedef, birbirine benzeyen verileri, belirli kavramlar ve temalar altında toplamak ve bunları kişilerin anlayabileceği şekilde düzenlemek ve açıklamaktır (Yıldırım ve Şimşek, 2011). Öte yandan içerik analizinde görüşmeler yoluyla elde edilen nitel araştırma verileri dört aşamada analiz edilmektedir. Bunlar; verilerin kodlanması, temaların bulunması, kodların ve temaların düzenlenmesi, bulguların tanımlanması ve yorumlanmasıdır (Çepni, 2012). Betimsel analizin amacı ise, bir olayın nasıl ortaya çıktığını ve sürdügünü ya da bir durumun, neye benzediğini tasvir etmek ve karmaşık şeyleri daha anlaşılabilir hale getirme çabası içine girmektir (Punch, 2005).

\section{Bulgular}

Bu bölümde öğretmen görüşme formundan elde edilen veriler tablolar haline getirilmiştir. Araştırmanın soruları; beş başlık altında toplanarak analiz edilmiştir. Bu başlıklar sırasıyla öğretmenlerin; sanat ve yaratıcılık kavramıyla ilgili görüşleri, öğrenme ortamında uyguladıkları sanat ve yaratıcılıkla ilgili faaliyetlerin neler olduğu, bu sanat faaliyetlerin çocukların yaratıcılıkları üzerindeki etkileri, uyguladıkları sanat ve yaratıcı faaliyetlerin öğrencilerin gelişim süreçleri üzerindeki etkisine yönelik görüşleri ile sanat ve yaratıcılık açısından kendilerini nasıl tanımladıklarına yönelik görüşleri başlıkları altında toplanarak açıklanmıştır.

\subsection{Okul Öncesi Öğretmenlerinin Sanat ve Yaratıcılık Kavramlarıyla İlgili Görüşleri}

Öğretmenlerinin sanat ve yaratıcılıkla ilgili görüşleri Tablo 1 'de verilmiştir.

Tablo1: Öğretmenlerin sanat ve yaratıc1lıkla ilgili görüşleri

\begin{tabular}{llcc}
\hline \multicolumn{1}{c}{ Tema } & \multicolumn{1}{c}{ Kodlar } & N & \% \\
\hline Sanatla ilgili & & 47 & $\% 100$ \\
görüşleri & & & \\
& & 10 & $\% 22$ \\
& Duygu, düşünce ve hayal & 10 & $\% 22$ \\
& Özgün bir ürün oluşturma & 8 & $\% 18$ \\
& Karşı tarafa mesaj verme & 6 & $\% 11$ \\
& Üstün yaratıc1lı & 5 & $\% 10$ \\
& Sonsuzluk & 5 & $\% 10$ \\
& Hayatın rengi & 3 & $\% 7$ \\
\hline Yaratıcılıkla & Yetenek & 35 & \\
ilgili & & & \\
görüşler & & & \\
& Kendini ifade etme şekli & 15 & $\% 42$ \\
& Özgünlük & 11 & $\% 31$ \\
& Farklılık & 5 & $\% 14$ \\
& Estetik & 4 & $\% 11$ \\
& Kendini tanıtmak & 1 & $\% 2$ \\
\hline
\end{tabular}


Tablo 1 incelendiğinde, öğretmenlerin sanat ve yaratıcılıkla ilgili görüşlerine ilişkin olarak sanat ile ilgili olarak sırasıyla yineledikleri görüşlerinin; duygu, düşünce ve hayal (n:10\%22), özgün bir ürün oluşturma (n:10-\%22), karş1 tarafa mesaj verme şekli (n:8-\%18), üstün yaratıcılık (n:6-\%11), sonsuzluk (n:5-\%10), hayatın rengi(n:5-\%10), yetenek(n:3-\%7) olduğu görülmektedir. Öğretmenlerin yaratıcılıkla ilgili olarak en sırasıyla yineledikleri görüşlerin; kendini ifade etme şekli(n:15-\%42), özgünlük(n:11-\%31), farkl1lık (n:5-\%14), estetik(n:4-\%11) ve kendini tanıtmak (n:1-\%2) olduğu görülmektedir. Ö.14. kodlu öğretmen duygu, düşünce ve hayal kodlu cevabını "Sanat; duygu, düşünce ve hayal ve gözlemlerimizin hayat bulduğu bir kavramdır. Ruhumuzda hissettiklerimizin anlam kazanmasıdır." Ö4. kodlu öğretmen özgün bir ürün oluşturma kodlu cevabını "Aklımızda var olan düşüncelerimizden yola çıkarak özgün ve yeni ürünler ortaya çıkarmaktır." Ö30. kodlu öğretmen karşı tarafa mesaj verme şekli kodlu cevabını "Birbirimizi anlamanın birilerine kendimizi anlatmanın en güzel yoludur. ” Ö.9. kodlu öğretmen üstün yaratıcılık kodlu cevabını "Kişinin kendi yetenekleri doğrultusunda ürettiği en güzel yapıt şeklinde tanımlamıştır. " Ö.12. kodlu öğretmen sonsuzluk kodlu cevabını "Sanatı kişinin kendi içindeki sonsuz yolculuğu olarak tanımlamak mümkündür." Ö.25. kodlu öğretmen hayatın rengi kodlu cevabında "Sanatın kişinin kendi yaşamında yaptıkları veya yapamadiklart şeyler gibi siyah ve beyaz renklerden oluştuğunu diğer renklerin ise hayatımızdaki dalgalanmaları yansıttı̆̆ını ifade etmiştir." Ö.7. kodlu öğretmen yetenek kodlu cevabında "Çocukların beceri ve yeteneklerini dışa vurma şekli olarak tanımlamıştır. "Yaratıcılık temasına ilişkin olarak Ö.8 kodlu öğretmen kendini ifade etme şekli kodlu cevabını "Kişinin kendisini ifade etmek için kullandığı en etkili yol" olarak tanımlamıştır. Ö.33. kodlu öğretmen özgünlük kodlu cevabımda "Çocuğun veya kişinin yaptığl etkinliklerde özgün şekilde hiçbir basklya maruz kalmadan ürün ortaya çıkarmasıdır." Ö.40. kodlu öğretmen farklılık kodlu cevabında "Çocuğu diğer çocuklardan ayıran farklı fikirleri ve arayışlarıdır." Ö. 32. kodlu öğretmen estetik kodlu cevabında "Elini attığın herhangi bir şeye güzellik, incelik ve estetik bir bakış açısı katmaktır." Ö.29. kodlu öğretmen kendini tanıtmak olarak kodlu cevabını "Yaptıklarınla, ettiklerinle insanlara kendini tanitmaktır." şeklinde ifade ettikleri belirlenmiştir.

Sanat ve yaratıcılıkla ilgili olarak okul öncesi öğretmenlerinin bu kavramları soyut ve duyuşsal cümlelerle açıklamayı tercih ettikleri bu anlamda okul öncesi eğitim döneminde öğretmenlerin yapacakları etkinliklerin öğrencilerin soyut düşünme becerileri ile duyuşsal gelişimlerini olumlu yönde etkileyeceğini söylemek mümkündür. Ayrıca öğretmenlerin konuyla ilgili yaptıkları açıklamalar analiz edildiğinde bu görüşleri destekler nitelikte açıklamalara yer verdikleri görülmektedir.
3.2. Öğrenme Ortamında Uyguladıkları Sanat ve Yaratıc1lıkla İlgili Faaliyetlere İlişkin Görüşleri

Öğretmenlerin öğrenme ortamında uyguladıkları sanatsal faaliyetlere ilişkin görüşleri Tablo 2'de verilmiştir.

Tablo 2: Öğrenme ortamında uyguladıkları sanatsal faaliyetler

\begin{tabular}{lllc}
\hline \multicolumn{1}{c}{ Tema } & \multicolumn{1}{c}{ Kodlar } & N & \% \\
\hline Sanatsal & Resim çizme ve Boyama Etkinlikleri & 40 & $\% 29$ \\
faaliyetler & Kâğıt katlama ve Origami Etkinlikleri & 33 & $\% 24$ \\
& Kâğıt Kesme ve Yapıştırma Etkinlikleri & 30 & $\% 22$ \\
& Oyun Hamurları Etkinlikleri & 18 & $\% 13$ \\
& Proje ve Grup Etkinlikleri & 11 & $\% 8$ \\
& Diğer Sanat Etkinlikleri & 5 & $\% 4$
\end{tabular}

Tablo 2 incelendiğinde, okul öncesi öğretmenlerinin öğrenme ortamında uyguladıkları sanatsal faaliyetlere ilişkin yineledikleri görüşlerinin sırasıyla; öğrencilerine resim çizme ve boyama etkinlikleri (n:40- \%29), kâğıt katlama ve origami çalışmaları (n:33-\%24), kâğıt kesme ve yapıştırma etkinlikleri (n: 30-\%22), oyun hamurlarıyla ilgili etkinlikler (n:18-\%13), proje ve grup etkinlikleri (n:11-\%8) ve diğer sanat etkinlikler(n:5-\%4) yaptırdıklarını ifade etmişlerdir. Ö.8 kodlu öğretmen resim çizme ve boyama etkinlikleri kodlu cevabında "Çocukların el kaslarl ve zihinsel koordinasyonları gelişsin diye etkinliklerde onlara sık sık resim çizdiriyor ve boyama yaptırıyorum." Ö. 11 kodlu öğretmen kâğıt katlama ve origami kodlu cevabında "Çocukların yaratıcılıklarını kağltlara şekil verirken izlemek ve tanık olmak çok güzel. ” Ö.5 kodlu öğretmen kâğıt kesme ve yapıştırma kodlu cevabında "Onların ince kas koordinasyonlarının gelişimi için bu tarz çalışmaları çok sılk yaptırıyorum. Büyük keyif alıyorlar. ” Ö. 35 kodlu öğretmen oyun hamurları kodlu cevabında "Oyun hamurlarlyla her gün yeni bir şeyler inşa ediyoruz. Birisi bir köşede ev yapıyor, birisi doğum günü pastast, birisi oyuncak araba...Ne ararsanız var..." Ö. 19 kodlu öğretmen proje ve grup etkinlikleri kodlu cevabında "Sağlıkl beslenmenin önemini anlatmak için ögrencilerimle yemeklerini yerlerde daha güçlü olacaklarını söyleyerek düzenli ve dengeli beslenmenin önemini anlattım onlara. Sonra hep birlikte gidip yemeklerimizi yedik. Yemeklerini bitiren çocukların pazularına dokunarak şiştiğini söyledim. Yanaklarının kıpkırmızı olduğunu vurguladım. Çok hoşlarına gitti.” Ö. 20 kodlu öğretmen diğer sanat etkinlikleri kodlu cevabında "Bir defasında okulda dolaplarımızda kalan atık malzemelerimizle vücudumuzun bölümlerini yapmaya çalıştık. Ortaya ilgi çekici şeyler çıktı." şeklinde ifade etmişlerdir.

Okul öncesi öğretmenlerinin öğrenme ortamında uyguladıkları sanatsal etkinliklere bakıldığında, öğretmenlerin çoğunlukla zaman, mekân ve kaynak açısından daha ekonomik ve sınıf içinde uygulanabilir etkinlikleri yer verdikleri görülmektedir. Öğretmenlerin okul öncesi eğitim döneminde bu türden sanatsal faaliyetlere daha fazla yer vermelerindeki en önemli etkenlerden biri de çocukların, el ve zihin koordinasyonunu geliştirerek onları temel eğitime hazırlama arzusu olabilir. 
3.3. Uyguladıkları Sanat Faaliyetlerin Çocukların Yaratıcılıkları Üzerindeki Etkisine Yönelik Görüşleri

Okul öncesi öğretmenlerinin uyguladıkları sanat faaliyetlerin çocukların yaratııılıkları üzerindeki etkisine yönelik görüşleri Tablo 3'de verilmiştir.

Tablo 3: Uyguladıkları sanatsal faaliyetlerin çocukların yaratıcılıkları üzerine yansımaları

\begin{tabular}{clcc}
\multicolumn{1}{c}{ Tema } & \multicolumn{1}{c}{ Kodlar } & N & \% \\
\hline Yaratıcılıkla & Bireysel yeteneklerini fark etme & 32 & $\% 40$ \\
ilgili & Grup çalışmalarında artış & 19 & $\% 24$ \\
yansımaları & Özgün eserler çıkarma & 14 & $\% 18$ \\
& Neden sonuç ilişkisi kurma & 9 & $\% 11$ \\
& Daha uzak hedefler belirleme & 6 & $\% 7$ \\
\hline
\end{tabular}

Tablo 3 incelendiğinde, okul öncesi öğretmenlerinin öğrenme ortamında uyguladıkları sanatsal faaliyetlerin çocukların yaratıcılıkları üzerindeki etkisine ilişkin yineledikleri görüşlerin sırasıyla; öğrencilerinin bireysel yeteneklerini tanımalarını sağladığını $\quad(\mathrm{n}: 32-\% 40), \quad$ grupla yapılan çalışmalarda artış olduğunu(n:19-\%24), özgün eserler çıkarma (n:14- \%18), olaylar arasında neden sonuç ilişkisi kurmalarına yardımcı olduğunu(n:9-\%11) ve daha uzak hedefler belirlemelerini sağladığını (n:6- \%7) ifade etmişlerdir. Ö. 6 kodlu öğretmen bireysel farklılıkların farkına varma kodlu cevabında "Her yaptırdı̆̆ım sanatsal faaliyetlerin sonunda ögrencilerimin bireysel olarak birbirinden farkl yeteneklerini keşfetme șansı yakalıyorum. Buda benim onları daha yakından tanımama ve nelere daha çok ilgi duyduklarını anlamama olanak sağllyor" Ö.20 kodlu öğretmen grup çalışmalarında artı̧ kodlu cevaplarında "Yaptığımı sanatsal etkinliklerde ögrencilerimin birbirleriyle daha çok bir arada çalıștıklarını fark ettim. Bazen bu durum etkinliklerin doğasından kaynaklanlyorken, genel olarak ögrrencilerim bu tür faaliyetleri gruplaşarak yapmayl tercih ediyorlar." Ö.38 kodlu öğretmen özgün eserler ortaya çıkarma kodlu cevabında "Öğrencilerimin yaptığ çalışmalara baktı̆ımda kendilerine ait çok daha eserler ortaya çıkardıklarını gördüm.” Ö.25 kodlu öğretmen neden sonuç ilişkisi kurma kodlu cevabında "Bu tür etkinliklerin sonunda öğrencilerimin yaptıkları sanatsal faaliyetlerle ilgili sebep ve sonuç ilişkilerini daha kolay kurduklarına tanık oldum.” Ö. 17 kodlu öğretmen daha uzak hedefler belirleme kodlu cevabında "Öğrencilerim bir sanatsal etkinliğe başladığımızda bu etkinliklerin sonucunu neler ortaya çıkacağını düşünerek ve planlayarak hareket ediyorlar" şeklinde belirtmişlerdir.

Okul öncesi eğitim döneminde uygulanan sanatsal faaliyetlerin çocuklarda yaratıcı düşünmenin temel öğelerinden olan olaylar arasında neden sonuç ilişkisi kurma ve özgün eserler ortaya çıkarma gibi unsurlar arttırdığı belirlenmiștir. $\mathrm{Bu}$ nedenle okul öncesi eğitim döneminde uygulanan sanatsal faaliyetlerin çocuklarda yaratıcı düşünme becerilerini geliştirdiği söylemek mümkündür.
3.4. Uyguladıkları Sanatsal ve Yaratıcı Faaliyetlerin Çocukların Gelişim Süreçleri Üzerindeki Etkisine Yönelik Görüşleri

Okul öncesi öğretmenlerinin uyguladıkları sanatsal ve yaratıcı faaliyetlerin çocukların gelişim süreçleri üzerindeki etkisine yönelik görüşleri Tablo 4'de verilmiştir.

Tablo 4: Gelișim süreçleri üzerindeki etkisi

\begin{tabular}{clcc}
\hline \multicolumn{1}{c}{ Tema } & \multicolumn{1}{c}{ Kodlar } & N & \% \\
\hline Gelişim süreçleri & Sosyal gelişimlerinde & 11 & $\% 26$ \\
üzerindeki etkisi & Duygusal gelişimlerinde & 10 & $\% 24$ \\
& Dil gelişiminde hızlanma & 8 & $\% 19$ \\
& Bilişsel gelişimlerinde & 5 & $\% 12$ \\
& Psikomotor gelişimlerinde & 4 & $\% 10$ \\
& Öz bakım becerilerinde & 3 & $\% 9$ \\
\hline
\end{tabular}

Tablo 4 incelendiğinde, okul öncesi öğretmenlerinin öğrenme ortamında uyguladıkları sanat faaliyetlerin çocukların gelişim süreçleri üzerinde etkisine yönelik olarak yineledikleri görüşlerinin sırasıyla; öğrencilerinin sosyal gelişimlerini (n:11-\%26), duygusal gelişimlerini (n:10-\%24), dil gelişimlerini ( $\mathrm{n}: 8-\% 19)$, bilişsel gelişimlerinde ( $\mathrm{n}: 5-\% 12)$, Psikomotor gelişimlerini (n:4-\%10) ve öz bakım becerilerini arttırdığını (n:3-\%9) ifade etmiş̧lerdir. Ö.9 kodlu öğretmen öğrencilerin sosyal gelişimlerini arttırma kodlu cevabında "Yaptı̆̆ımı sanat ve yaratıcllkkla ilgili faaliyetlerde ögrencilerimin aldikları sorumluluklart yerine getirmek için çaba gösterdiklerini ve birbirleriyle çok daha kolay iletişim kurduklarını gördüm" Ö.40 kodlu öğretmen duygusal gelişim kodlu cevabında " $\mathrm{Bu}$ tip faaliyetler ögrencilerimin bir şeylerden hoşlanıp hoşlanmadıklarını belli etmelerinde çok etkili oldu. Bu etkinlikler sayesinde ögrencilerimin bireysel olarak duygusal gelişsimlerini daha yakından bilir oldum”. Ö. 25 kodlu öğretmen dil gelişimlerini artırma kodlu cevabında "Öğrencilerimle öğrenme ortaminda bu tür faaliyetlerde bulunurken üzerinde çalıştığımı nesneler ve objelerle ilgili ilişki kurarak anlamlı cümleler kurduğunu fark ettim”. Ö.7 kodlu öğretmen bilişsel gelişimlerini artırdığı kodlu cevabında "Bu tür faaliyetlerin çocukların nesneler ve objeler arasındaki benzer ve farkl yönleri keşfetmelerini sağlamada çok önemli bir işlevi olduğunu fark ettim”. Ö.30 kodlu öğretmen psikomotor gelişimlerini artırma kodlu cevabında "Öğrencilerimle sinıf ortamında bu tür etkinlikler üzerinde çalışırken genelde müzik dinleyerek ve şarkı söyleyerek çalışıyoruz. Öğrencilerim bu müziklere ve şarkılara çok rahatllkla ritim ve tempo tutabiliyorlar" Ö. 11 kodlu öğretmen öz bakım becerilerini artırma kodlu cevabında "Öğrencilerim yapacağımız etkinliklere uygun kllik klyafet giyme sorumluluğunu kendileri almaya başladılar. Bunu görmek beni çok mutlu ediyor."

Okul öncesi eğitim döneminde uygulanan sanatsal ve yaratıcı faaliyetlerin çocukların gelişimlerini her yönüyle desteklediği görülmektedir. Bu nedenle bu dönemde yer verilecek sanatsal etkinliklerin çocukların gelişim süreçleri üzerinde oldukça önemli bir yeri olduğunu söylemek mümkündür. Öğretmenlerin görüşlerinden elde edilen bulgularda bu sonuçları destekler niteliktedir. 


\subsection{Sanat ve Yaratıcılık Açısından Kendilerini Nasıl Tanımladıklarına Yönelik Görüşleri}

Okul öncesi öğretmenlerinin sanat ve yaratıcılık açısından kendilerini nasıl tanımladıklarına yönelik görüşleri Tablo 5'te verilmiştir.

Tablo 5: Sanat ve yaratıcılık açısından kendilerini nasıl tanımladıklarına yönelik görüşleri

\begin{tabular}{llcc}
\hline \multicolumn{1}{c}{ Tema } & \multicolumn{1}{c}{ Kodlar } & N & \% \\
\hline Kendilerini Nasıl & Çok yeterli & 6 & $\% 15$ \\
Tanımladıkları & Yeterli & 7 & $\% 18$ \\
& Kısmen yeterli & 17 & $\% 43$ \\
& Yetersiz & 5 & $\% 12$ \\
& Çok yetersiz & 5 & $\% 12$ \\
\hline
\end{tabular}

Tablo 5 incelendiğinde, okul öncesi öğretmenlerinin sanat ve yaratıcılık açısından kendilerini nasıl tanımladıklarına yönelik olarak yineledikleri görüsslerinin sırasıyla; kısmen yeterli (n:17-\%15), yeterli (n:7-\%18), çok yeterli (n:6-\%15), yetersiz (n:5-\%12) ve çok yetersiz oldukları şeklinde (n:5-\%12) ifade etmişlerdir. Ö. 15 kodlu öğretmen kısmen yeterli kodlu cevabında "Sanat ve yaratıcıllkla ilgili konularda kendimi kısmen yeterli görüyorum ama bu konuda güncel ve yeni desteklere ihtiyacım olduğunu düşünüyorum”. Ö. 4 kodlu öğretmen yeterli kodlu cevabında "Bu konuda kendimi yeterli görüyorum. İnternetten konuyla ilgili paylaşımları takip edip ögrenme ortamında öğrencilerime uyguluyorum." Ö. 8 kodlu öğretmen çok yeterli kodlu cevabında "Kendimi bu konuda çok yeterli görüyorum. Bunu sağlayabilmek için konuyla ilgili güncel internet paylaşımlarını takip ediyorum. Ayrıca sanatsal ve kültürel faaliyetlere bol bol zaman ayırıyorum. Zümre arkadaşlarımla konuyla ilgili görüş alışverişinde bulunuyorum. Gezmeyi ve dolaşmayı çok seviyorum. Kitap okumakta en büyük hobim" Ö. 19 kodlu öğretmen yetersiz kodlu cevabında "Sanat ve yaratıcıllk konusunda kendimi yetersiz hissediyorum. Bu tür etkinliklere sınıf içerisinde ara stra yer vermeyi tercih ediyorum” Ö. 37 kodlu öğretmen çok yetersiz kodlu cevabında "Meslekte otuzuncu yılım. Artık bir şeyleri takip edip uğraşmıyorum. Sinıfimda bu tür etkinlikler yapmıyorum." şeklinde ifade etmişlerdir.

Okul öncesi eğitim döneminde çocukların soyut düşünme, yaratıcı düşünme, gelişim süreçlerini tüm yönleriyle destekleme ve onları temel eğitime hazırlama anlamında çok büyük katkısı olduğu anlaşılan sanat ve yaratıcılık etkinliklerinin bu konuda kendini çok daha fazla yeterli hissedecek olan öğretmenlerle hayat bulacağı bir gerçektir.

\section{Tartışma, Sonuç ve Öneriler}

$\mathrm{Bu}$ araştırmada, okul öncesi öğretmenlerin sanat ve yaratıcılık kavramlarıyla ilgili algıları belirlenmeye çalışılmıştır. Bu amaç doğrultusunda şu sonuçlara ulaşılmıştır:

Okul öncesi eğitim döneminde öğretmenler tarafından uygulanan sanat ve yaratıcılıkla ilgili etkinliklerin çocuklara soyut düşünme becerileri kazandırdığı ve onların duyuşsal gelişimleri üzerinde olumlu katkı sağladığı tespit edilmiştir. Okul öncesi eğitim döneminde öğretmenlerin sanat ve yaratıcılıkla ilgili öğrenme sürecinde yapılacak etkinliklerin, çocukların soyut öğrenme becerilerini somutlaştırarak öğretmeye yardımcı olacak çok sayıda materyal kullanılmasına olanak sağlayabilir. Ayrıca konuyla ilgili olarak öğretmenlerin bu dönemde daha çok zaman, mekân ve kaynak açısından ekonomik ve sınıf içerisinde uygulanabilir sanat ve yaratıcılıkla ilgili etkinliklere yer verdikleri belirlenmiştir. Okul öncesi eğitim döneminde öğretmenlerinin sanat ve yaratıcılıkla ilgili olarak zaman, mekân ve materyal yönünden ekonomik ve sınıf içinde uygulanabilir çalışmaları tercih ediyor olmaları öğrencilerin bireysel farklılıklarını ön plana çıkarmak için yapılan sanatsal ve yaratıcı faaliyetlerin belirli ölçütlerle sınırlandırılması çocukların özgün ve farklı düşüncelerini öğrenme sürecine tam anlamıyla yansıtmalarını engelleyen bir algıyı ortaya çıkarabilir.

Okul öncesi eğitim döneminde öğretmenler sanat ve yaratıcılıkla ilgili yaptırdıkları çalışmaların öğrenme sürecinde bir yandan çocukların el ve zihin koordinasyonlarını geliştirmeye çalışırken, bir yandan da çocukları temel eğitime hazırlamaya çalıştıkları belirlenmiştir. Görüldüğü gibi öğretmenlerin okul öncesi eğitim döneminde sanat ve yaratıcılıkla ilgili yaptırdıkları etkinliklerin çocukların psikomotor becerilerinin gelişiminde de önemli bir rol üstlendiği söylemek mümkündür. Aynı süreçle ilgili olarak öğretmenlerin konuyla ilgili yaptıkları çalışmaların çocukların yaratıcı düşünme becerilerini geliştirdiği tespit edilmiştir. Bununla birlikte, bu tür etkinliklerin çocukların gelişim süreçlerini her yönüyle desteklediği ancak öğretmenlerin sanat ve yaratıcılık konusunda kendilerini tam anlamıla yeterli hissetmedikleri belirlenmiştir. Araştırmadan elde edilen bu verilere göre okul öncesi öğretmenlerinin sanat ve yaratıcılık konusunda mesleki anlamda hizmet içi eğitime ihtiyaç duydukları söylenebilir.

Bu kapsamda okul öncesi öğretmenlerinin sanat ve yaratıcılık kavramıyla ilgili görüşleri boyutunda okul öncesi öğretmenlerinin, büyük çoğunluğu sanat kavramıyla ilgili görüşlerini; çocuğun duygularını, düşüncelerini ve hayallerini ifade etme şekli, özgün bir ürün oluşturma süreci, karşı tarafa mesaj vermenin bir yolu ve üstün yaratıcılık kavramlarıyla açıkladıkları görülmektedir. Öte yandan okul öncesi öğretmenleri, yaratıcılık kavramını çoğunlukla çocuğun kendini ifade etme şekli ve özgünlük kavramılyla açıklamışlardır. Özgünlük, yaratıcılığın önemli parçalarından biridir. Bu doğrultuda düşünen çocukların problem çözme ve fikir üretme konusundaki becerileri daha çok gelişmiştir (Runco, Illies ve Eisenman, 2005). Ortaya ç1kan bu sonuçlardan da anlaşıldığı gibi okul öncesi öğretmenlerinin sanat ve yaratıcılık kavramına yönelik algılarının kısmen birbirine benzediği ve dolayısıyla bu kavramların okul öncesi öğretmenleri tarafından iç içe geçmiş kavramlar olarak algılayarak kullandıklarını söylemek mümkündür. Bununla birlikte sanat ve yaratıcık kavramıyla ilgili olarak okul öncesi öğretmenlerinin tamamının olumlu görüş belirtikleri tespit edilmiştir. Elde edilen bu veriler doğrultusunda okul öncesi öğretmenlerinin sanat ve yaratıcılık konusunda evrensel düşünce ve değerlere sahip oldukları belirlenmiştir. Aykanat (2018) tarafindan yapılan araştırmada, okul öncesi öğretmenlerinin sanat eğitimine yönelik olumlu bir tutum sergiledikleri, sanattan hoşlandıkları ve sanatın katkısına inandıkları $(\% 94,6)$, sanata karşı olumsuz tutum göstermedikleri $(96,84)$, iletişimi artırıcı bir rolü olduğuna $(92,76)$ yüksek ölçüde inandıkları ve oldukça önemli olduğunu düşündüklerini $(\% 87,6)$ tespit ettikleri araştırma sonuçlarıyla benzer sonuçlara ulaşıldığı görülmektedir.

Okul öncesi öğretmenlerinin öğrenme ortamında uyguladıkları sanat ve yaratıcılıkla ilgili faaliyetlerin neler olduğu boyutunda öğretmenlerin, öğrencilerine en çok resim çizme ve boyama etkinlikleri yaptırdıkları belirlenmiştir. Okul öncesi eğitimde 
öğretmenlerin sanatsal faaliyet olarak en çok resim çizme ve boyama çalışmalarına yer vermesinin nedeni okul öncesi ögretmenlerin sanatsal faaliyetler konusunda yeterince bilgi ve donanıma sahip olmamalarından kaynaklanıyor olabilir. Öte yandan çocuğun dünyasında resim her zaman önemli bir yere sahip olmuştur. Başlangıçta oyun olarak çizdiği karalamalar, zamanla bedensel ve zihinsel gelişimlerine bağlı olarak, büyükler tarafından anlaşılan birer anlamlı çizgi şeklini alırlar (Aydın, 2017). Konuyla ilgili literatür taramasında bu araştırma sonuçlarını destekleyen başka araştırma sonuçlarının da olduğu tespit edilmiştir. Özkan ve Girgin (2014) göre okul öncesi öğretmenlerin \%76,5 inin görsel sanat etkinliklerine her gün yer verdikleri, $\% 52,9$ unun en çok boyama çalışmalarını tercih ettikleri ve \%47,1 inin bu etkinliklerde anlatım yöntemini kullandığı sonucuna ulaşılmıştır. Makhmalbaf ve YiLuen Do (2007) ile Pandit ve Neogi'nin (2016) yaptığı çalışmalarda, okul öncesi dönemdeki çevresel faktörlerin çocukların yaratıcılığı üzerine önemli etkisinin olduğu ve çocuklara zengin materyal, malzeme ve oyuncak sunulan eğitim ortamlarında çocukların yaratıcı düşünmelerinde olumlu yönde değişiklikler meydana getirdiğini belirlemiştir.

Okul öncesi öğretmenleri, öğrenme ortamında uyguladıkları sanatsal faaliyetlerin çocukların yaratıcılıkları üzerinde çoğunlukla, kendi bireysel yeteneklerinin farkına varmalarını sağladığını ifade etmişlerdir. Görüldüğü gibi okul öncesi eğitimde uygulanan bu tür faaliyetlerin çocukların kendi bireysel yeteneklerini keşfetmede önemli bir rol üstlenebilir. Bununla birlikte okul öncesi öğretmenlerinin eğitim sürecinde uyguladıkları sanatsal faaliyetlerin çeşitliliği öğrenme sürecini daha nitelikli ve zengin hale getirecektir. Bu araştırma sonucunu destekleyen bir araştırmada, Sunday (2015) yaptığı, sanat eğitimi hakkındaki geleneksel düşünceyi değiştirmeyi ve bu alanın erken çocukluk eğitiminde farklı potansiyele sahip yönlerini keşfetmeyi amaçlayan çalışmasının sonucunda, sanatın çocuğa verdiği sanatsal ortamı ve fikirleri keşfetme şansına bağlı olarak, sanatın çocukların yaşamlarında önemli bir fonksiyonun olduğunu tespit etmiştir. Feeney ve Moravick (1987)'e göre, çocukların yaratıcılık ve estetik duyguları erken yaşlarda desteklenmezse ileriki yıllarda yaratıcı, üretken ve çevrelerindeki güzellikleri algılayan bireyler olmalarını da engelleyebilmektedir. Okul öncesi öğretmenleri, öğrenme ortamında uyguladıkları sanatsal faaliyetlerin çocukların çoğunlukla sosyal gelişimlerini hızlandırmada etkili olduğunu ifade etmişlerdir. Bu nedenle okul öncesi öğretmenlerinin öğrenme sürecinde uyguladıkları sanatsal faaliyetlerin çocukların dayanışma, yardımlaşma ve birlikte çalışma alışkanlıklarını kazandırmada önemli bir rol üstleneceği söylemek mümkündür. Bu araştırma sonuçları, Parlakyıldız ve Yıldızbaş (2006)'ın yaptığı öğretmenlerin çocuklara sağladıkları sanat eğitiminin onların gelişimleri üzerinde önemli katkılarının olduğunu belirledikleri araştırma sonuçlarıyla birbirini destekler niteliktedir.

Diğer bir araştırma sonucuna göre okul öncesi öğretmenleri sanat ve yaratıcılık konusunda genel olarak kendilerini kısmen yeterli bulduklarını ifade etmişlerdir. Okul öncesi öğretmenlerinin bu anlamda desteğe ihtiyaç duydukları görülmektedir. Bu nedenle okul öncesi öğretmenlerinin sanat ve yaratıcılık konusunda akademik ve bilimsel anlamda desteklenmeye ihtiyaç duyduklarını söylemek mümkündür. Literatür incelendiğinde bu araştırma sonucunu destekleyen başka araştırmalarda olduğu belirlenmiştir.
Aykanat (2018) yaptığı araştırmasında okul öncesi öğretmenlerinin, öğretmenlik eğitimi süreçlerinde aldıkları eğitim konusunda yetersizlikler hissettiklerini, sanatsal etkinlikler ve uygulamalar konusunda kendilerini yeterince gerçekleştiremedikleri sonucuna ulaşmıştır. Öte yandan Novaković'in (2015) okul öncesi öğretmenlerinin görsel sanat bilgisi, sanat etkinliklerinin rolü ve sanat etkinliklerinin uygulama sıklığı hakkındaki tutumlarını incelediği araştırmada okulöncesi öğretmenlerinin sürekli mesleki eğitim ve iyileştirme çalışmalarına katılmalarının önemli olduğu sonucuna ulaşmıştır. Yuvacı ve Dağlıoğlu (2018) yaptıkları çalışmasında öğretmenlerin sınıf ortamının yaratıcılık düzeyinin yüksek olduğunu düşünmelerine rağmen bunları çocukların yaratıcılık düzeylerine yeterince yansıtamadıkları düşündüklerini tespit etmiştir.

Elde edilen bu araştırma sonuçları doğrultusunda aşağıdaki önerilerde bulunulabilir:

- Öğretmenlere, sanat ve yaratıcılıkla ilgili etraflarında kolaylıkla ulaşabilecekleri zengin sanatsal ve kültürel yaşam olanakları sunulmalıdır.

- Okul öncesi eğitiminde uygulanan sanatsal ve yaratıcı faaliyetlerin çocukların üst düzey düşünme becerilerini arttırdığ1 ve gelişim süreçlerini her yönüyle desteklediği temel eğitime hazırlamadaki öneminden hareketle mevcut okul öncesi eğitim programında sanat ve yaratıcığa dönük etkinliklerin oranının arttırılması olumlu bir adım olabilir.

- Sanat ve yaratıcılıkla ilgili etkinliklerin öğretmenler tarafından daha çok sınıf içerisinde yapılan etkinliklerden oluştuğu bu nedenle öğretmenlerin sınıf dışında da yapılabilecek sanat ve yaratıcılıkla ilgili etkinlikler düzenlenmesi ve bunlara katılımlarının sağlanması konuyla ilgili önemli bir kazanım olabilir.

- Konuyla ilgili okul öncesi öğretmenlerinin yaptıkları ilgi çekici ve kapsayıcı çalışmaların sergilenebilmesi için Millî Eğitim Bakanlığı tarafından bir e-portal adresi düzenlenebilir.

- Okul öncesi eğitim döneminde sanat ve yaratıcılıkla ilgili olarak mevcut okul öncesi eğitim programlarında daha farklı ne tür etkinliklere yer verilebileceğine ilişkin araştırma konularına yer verilmesi alanına olumlu katkı sağlayabilir.

Araştırmacılara yönelik öneriler:

- Okul öncesi öğretmenlerinin sanat ve yaratıcılık kavramıyla ilgili algılarını belirlemeye yönelik yapılan bu araştırma örneklem grubu olarak farklı branş öğretmenleriyle de yapilabilir.

- Okul öncesi eğitim döneminde öğretmenlerin çocuklara sanat ve yaratıcılıkla ilgili daha çok sınıf içi etkinlikler yaptırdıkları görülmektedir. $\mathrm{Bu}$ nedenle okul öncesi ögretmenlerine yönelik olarak sınıf dışında da sanat ve yaratıcılık konusunda çocuklara ne tür etkinlikler yaptırılabileceklerine ilişkin yol gösterici çalışmalar yapılabilir.

\section{Kaynakça}

Artut, K. (2004). Okul öncesi resim eğitiminde çocukların çizgisel gelişim düzeylerine ilişkin bir inceleme. Çukurova Üniversitesi, Sosyal Bilimler Enstitüsü Dergisi, 13(1), 223-234. 
Aydın, Ö. U. (2017). Okul öncesi resim eğitiminde çocuğun çizgisel gelişimi (2-7 Yaş). Kastamonu Üniversitesi, Eğitim Dergisi, 25(6), 2215-2228.

Aykanat, E. (2018). Okul öncesi öğretmenlerinin sanat eğitimine yönelik tutumlarını belirlemek üzere ölçek geliştirme çalışması. (Yayınlanmamış yüksek lisans tezi). Başkent Üniversitesi Eğitim Bilimleri Enstitüsü, Ankara.

Barker, A. (2002). Yenilikçiliğin simyast. (Ed). Ahmet Kardam. İstanbul: MESS Yayınları.

Cevher-Kalburan, N. (2012). Erken çocukluk döneminde yaratıcılık ve sanat. Ankara: Eğiten Kitap.

Çepni, S. (2012). Araştırma ve proje çalışmalarına giriş. Bursa: Celepler Matbaacilık.

Dinç, B. (2015). Okul öncesi eğitim kurumuna devam eden çocukların ebeveynlerinin çocuk hakları eğitimi konusundaki görüşleri. Eğitimde Nitel Araştırmalar Dergisi- ENAD, 3(1), 7-23.

Feeney, S, \& Moravcik, E. (1987). A thing of beauty: Aesthetic development in young children. Young children, 42(6), 7-15.

Garvis. S. (2012). Exploring current arts practice in kindergartens and preparatory classrooms. Australasian Journal of Early Childhood. 37(4), 8693.

Gönen, M., Aydos, E., H, \& Erdem, A., Ü. (2014). Experiences of candidate preschool teachers on art education and implementations, International Journal of Innovative Research in Education. http://sproc.org/ojs/index.php/IJIRE, 1(1), 10-17.

Güler, A., Halıcıŏ̆lu., M. B. ve Taşğın, S. (2013). Sosyal bilimlerde nitel araştırma. Ankara: Seçkin Yayıncilik.

Hardy, W. L. (2011). Arts in early childhood education and the enhancement of learning. (Unpublished doctoral thesis) Walden University. United States. Umi Number: 3478542.

Jackman, H. (2012). Early education curriculum: A child's connection to the world (Fifth Edition). Wadsworth Cengage Learning. U.S.A.

Kırışoğlu, O. (2002). Sanatta eğitim. Ankara: PegemA Yayıncılık.

Makhmalbaf, A., \& Yi-Luen, Do, E. (2007). Physical environment and creativity: Comparing children's drawing behavior at home and at the bookstore. International Association of Societies of Design Research the Honkong Polytechnic University, 1-22.

Merriam, S. (1998). Qualitative research and case study applications in education. San Francisco: JosseyBass

Novaković, S. (2015). Preschool teacher's role in the art activities of early and preschool age children. Croatian Journal of Education, 17(1), 153-163.

Lucas, C. (2014). An early childhood creative arts program in the state of California: A parallel study using four preschools. (Unpublished doktoral thesis). Jones International University, Umi Number: 3632230. U.S.A.

Özkan, B. ve Girgin, F. (2014). Okul öncesi öğretmenlerinin görsel sanat etkinliği uygulamalarını değerlendirmesi. December/Aralı, Electronic Journal of Vocational Colleges, 4(4), 79-85.

Pandit, N., \& Neogi, S. (2016). A study on the impact of preschool factors on creativity of young children. Facilities, 1(30), 271-231.

Parlakyıldız, B. ve Yıldızbaş, F. (2006). Okul öncesi ögretmenlerin sanat etkinlikleri 79 uygulamalarının bazı değişkenlere göre incelenmesi. Avrupa Birliği sürecinde okulöncesi eğitimin bugünü ve geleceği sempozyumu. İstanbul: Ya-Pa, 291-308.

Patton, M. Q. (1987). How to use qualitative methods in evaluation. Newbury Park, CA: SAGE Publications.

Runco, M. A., Illies, J. J., \& Eisenman, R. (2005). Creativity, originality, and appropriateness: What do explicit instructions tell us about their relationships? The Journal of Creative Behavior. 39(2), 137-148.

Punch, K. F. (2005). Sosyal araştırmalara giriş nitel ve nicel yaklaşımlar (D. Bayrak, H. B. Arslan ve Z. Akyüz, Çev.). Ankara: Siyasal Kitabevi.

Sawyer, R. K. (2011). Explaining creativity: The science of human innovation. New York, NY: Oxford University Press.

Senemoğlu, N. (2004). Gelişim öğrenme ve öğretim. Ankara: Gazi Kitapevi.

Solso, R. L., Maclin, M. K., \& Maclin, O. H. (2007). Bilişsel psikoloji (Çev. Ayşe Ayçiçeği-Dinn). İstanbul: Kitabevi Yayınları.

Sunday, K. E. (2015). Relational making: Re/imagining theories of child art. Studies in Art Education: A Journal of Issues and Research in Art Education, 56(3), 228-240.

Ulutaş, İ. ve Ersoy, Ö. (2004). Okul öncesi dönemde sanat eğitimi. Kastamonu Eğitim Dergisi, 12(1), 45-51.

Uysal, A. (2005). İlköğretimde verilen sanat eğitimi derslerinin yaratıcılığa etkileri. Gazi Üniversitesi Kırşehir Eğitim Fakültesi Dergisi, 6(1), 41-47.

Yavuzer, H. (2005). Çocuk psikolojisi. İstanbul: Remzi Kitabevi.

Yazıcı, E., Baydar, I. Y. ve Pınarcık. Ö.(2016). Okul öncesi öğretmenlerinin sanata ilişkin görüşlerinin incelenmesi. E Uluslararası Eğitim Araştırmaları Dergisi. 7(3), 74-88, DOI: 10,19160/e-ijer.80596.

Yuvacı, Z. ve Dağlığlu, E. H. (2018). Okul öncesi eğitim alan çocukların ve bulundukları sınıf ortamının yaratıcılık düzeyleri arasındaki ilişkisinin incelenmesi. Erken Çocukluk Çalışmaları Dergisi. 2(2), 234-256.

Yıldırım, A. ve Şimşek, H. (2011). Sosyal bilimlerde nitel araştırma yöntemleri. Ankara: Seçkin yayıncılık.

Yin, R. K. (2018). Case study research and applications design and methods (6). USA: Sage Publications. 